Al-Tanzim : Jurnal Manajemen Pendidikan Islam

\title{
PARTISIPASI DALAM PENGAMBILAN KEPUTUSAN STRATEGIS DI PONDOK PESANTREN
}

\author{
Syuhud \\ Institut Agama Islam Syarifuddin, Lumajang, Indonesia \\ Email : syuhudlu@gmail.com
}

DOI: http://doi.org/10.33650/al-tanzim.v3i2.658

Received: September $2019 \quad$ Revised: Oktober 2019 Approved: November 2019

\begin{abstract}
:
Decision making is one of the leader's strategic tasks in carrying out his leadership duties. Therefore information, participation from various parties and aspects in the management system, will determine the quality of decisions made by the leadership. Kyai as the highest leader of pesantren will determine the direction of development and make quality long-term strategic decisions in the face of global change. The ability of Kyai in managing information from subordinates in society can be seen from his decision making methods, namely full power and power sharing. The focus of this research lies in how Kyai utilize and manage information to make a positive contribution to produce quality decisions in Pondok pesantren Kyai Syarifuddin, Lumajang ? This research uses a qualitative approach with case study. The results showed that Kyai as a leader in pesantren have full authority in decision making, both short and long term. However, However, the Kyai as leaders of pesantren still ask for input information from the pesantren administrators as a material consideration in making quality decisions. The quality of decisions determined by a leader is very dependent on the extent to which information material data considerations provide an influence on the outcome of the decision.
\end{abstract}

Key words : Participation, Decision Making, Strategy

\begin{abstract}
Abstrak
Pengambilan keputusan merupakan salah satu tugas strategis pemimpin dalam melaksanakan tugas kepemimpinannya. Oleh karena itu informasi, partisipasi dari berbagai pihak dan aspek dalam sistem manajemen, sangat menentukan terhadap kualitas keputusan yang ditetapkan oleh pimpinan. Kyai sebagai pimpinan tertinggi pesantren akan menentukan arah pengembangan dan membuat keputusan strategis jangka panjang yang berkualitas dalam menghadapi perubahan global. Kemampuan Kyai dalam mengelola informasi dari para bawahan dalam masyarakat, dapat dilihat dari metode pengambilan keputusannya yaitu full power dan power sharing. Fokus penelitian ini terletak pada bagaimana Kyai memanfaatkan dan mengelola informasi agar memberikan kontribusi positif untuk menghasilkan keputusan yang berkualitas di Pondok pesantren Kyai Syarifuddin, Lumajang?. Penelitian ini menggunakan pendekatan kualitatif jenis studi kasus. Hasil penelitian menunjukkan bahwa Kyai sebagai pemimpin di pondok pesantren memiliki otoritas penuh dalam pengambilan keputusan, baik jangka pendek maupun jangka panjang. Namun demikian, Kyai sebagai pimpinan pondok pesantren tetap meminta masukan informasi kepada para pengurus pesantren sebagai bahan pertimbangan dalam membuat keputusan yang berkualitas. Kualitas keputusan yang ditetapkan oleh seorang pemimpin sangat bergantung sejauhmana informasi data bahan pertimbangan memberikan pengaruh terhadap hasil keputusan.
\end{abstract}

Kata Kunci : Partisipasi, Pengambilan Keputusan, Strategi 


\section{PENDAHULUAN}

Kyai merupakan figur sentral yang selalu menjadi sorotan pertama bagi siapapun yang bicara tentang pesantren, sosok Kyai dipandang sebagai representasi dari sejarah, pertumbuhan, dan perkembangan pesantren yang di pimpinnya (Hefniy, 2016). Max Weber sebagai orang pertama yang menggunakan istilah kharismatik sebagaimana dikutip oleh Stephen P. Robbins (2015) menyebutkan bahwa; pemimpin kharismatik merupakan pemimpin yang luar biasa dan dianggap pahlawan oleh para pengikutnya. Dalam pandangan teori kepemimpinan kharismatik, Kyai dinobatkan sebagai orang yang dianggap memiliki kemampuan lebih dari semua orang yang terlibat dalam struktur organisasi, beliau dipandang memiliki keteladanan, kecakapan, moral, keyakinan harapan, dan motivasi yang tinggi bagi para pengikutnya sehingga para pengikutnya selalu memiliki komitmen dan loyalitas yang tinggi terhadap kepemimpinan Kyai (Dlofier, 1982).

Dalam perkembangan selanjutnya, di mana manajemen organisasi sudah mulai masuk dalam proses kepemimpinan di pondok pesantren, praktek organisasi yang dijalankan mengalami pergeseran, dari pendekatan kultural kepada pendekatan structural. Dengan demikian peran-peran yang menjadi tanggung jawab Kyai berkembang kepada fungsi struktural organisatoris dengan pembagian tugas kerja yang jelas (Syahrul, 2015). Pada kondisi ini peran Kyai tidak lagi menjadi dominan dalam perjalan manajemen organsiasi pesantren, keterlibatan semua struktur dan unsur dalam menjalankan manajemen organisasi menjadi penting dan tidak dapat terhindarkan. Konsep ini menuntut ketelibatan semuan unsur pimpinan, baik internal maupun eksternal (masyarakat) dalam rangka pengambilan keputusan. Dalam proses pengambilan keputusan, dibutuhkan keterlibatan semua pihak untuk memberikan informasi secara akurat sehingga keputusan yang dirumuskan yang terkait dengan perencanaan program pesantren yang akan dilakukan memiliki kualitas yang diharapkan oleh masyarakat pengguna jasa pendidikan (Bashori, 2017).

Banyak penelitian yang dilakukan oleh para praktisi maupun pakar manajemen pendidikan tentang pengembilan keputusan. Gündüz (2014) dalam penelitiannya mengemukakan bahwa partisipasi karyawan di perguruan tinggi memiliki kontribusi yang signifikan dalam pengambilan keputusan sehingga lebih efektif. Mager (2012) juga mengemukakan dalam penelitiannya bahwa; para siswa yang dilibatkan dalam pengambilan keputusan, ternyata dapat memberikan masukan yang berarti terhadap kualitas keputusan yang diambil oleh para pimpinan. Namun demikian terdapat pengambilan keputusan yang tidak dilakukan oleh para pemimpin di luar pesantren, yaitu pengambilan keputusan intuitif religius yang merupakan pengambilan keputusan yang khas dilakukan oleh para pimpinan pondok pesantren. 
Al-Tanzim : Jurnal Manajemen Pendidikan Islam E-ISSN: 2549-5720 P-ISSN: 2549-3663

Vol. 03 No. 02 (2019) : 37-48

https:// ejournal.unuja.ac.id/index.php/al-tanzim

Fokus penelitian ini terletak pada ikhtiar Kyai dalam memanfaatkan dan mengelola informasi yang ada di pesantren dalam mengambil keputusan strategis dan berkualitas di di Pondok pesantren Kyai Syarifuddin, Lumajang, sehingga hal tersebut menjadi keunikan dan kebaruan dalam penelitian ini sebagai bagian dari khazanah pengembangan ilmu manajemen pendidikan Islam.

\section{Kepemimpinan Pesantren}

Kajian tentang kepemimpinan memiliki keunikan dan terus memancing para peneliti untuk mengkajinya. Melalui berbagai karakter atau tipologi yang dimiliki oleh seorang pemimpin dalam menjalankan proses kepemimpinan organisasi, maka kajian tentang teori kepemimpinan menjadi terus berkembang dan para pakar selalu menunjukkan sikap dinamis, di mana mereka tidak pernah menemukan kata sekapat dalam merumuskan definisi tentang kepemimpinan ini. Hal ini karena kata kepemimpinan dalam implementasinya mengandung berbagai aspek yang dapat digunakan untuk melakukan pendekatan.

Kepemimpinan merupakan obyek kajian ilmiah yang menarik perhatian para peneliti untuk terus melihat proses dan perkembangan suatu kelompok yang melibatkan banyak orang dengan satu tujuan yang sama (Mulyadi, 2010). Istilah kepemimpinan merupakan penyampaian citra individu yang kuat dan dinamis tentang seorang pemimpin suatu pasukan, perusahaan, negara, dan ataupun organisasi (Yukl, 2015). Oleh karena itu, kepemimpinan sebagai subyek kajian menjadi sangat sulit untuk didefinisikan yang sama, dan bahkan para pakar peneliti juga dapat menggunakan berbagai perspektif.

Meskipun banyak definisi spesifik dapat dikutip, namun demikian sebagian besar tetap bergantung pada orientasi teoritis yang diambil. Selain pengaruh, kepemimpinan telah didefinisikan dalam hal proses kelompok, kepribadian, kepatuhan, perilaku tertentu, persuasi, kekuatan, pencapaian tujuan, interaksi, diferensiasi peran, inisiasi struktur, dan kombinasi yang dihadapi pemimpin organisasi (Luthans, 2011). Kepemimpinan adalah proses di mana individu mempengaruhi sekelompok individu untuk mencapai tujuan bersama. Dari pengertian ini, terdapat beberapa komponen dalam kepemimpinan yaitu; a) kepemimpinan adalah proses, b) kepemimpinan melibatkan pengaruh, c) kepemimpinan terjadi dalam kelompok, d) kepemimpinan melibatkan tujuan bersama (Northouse, 2013).

Islam sebagai agama yang rahmatan lil alamin, telah memberikan penjelasan tentang kepemimpinan. Hal tersebut termaktub dalam QS. alBaqarah ; 


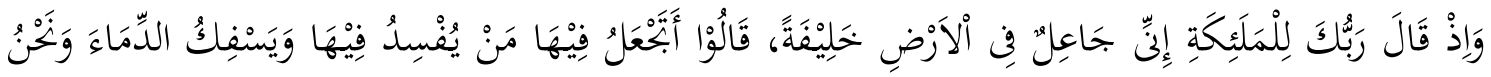

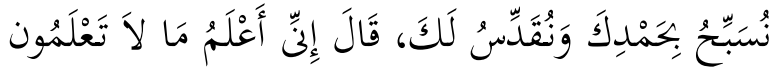

"Ingatlah ketika Tuhanmu berfirman kepada Malaikat: "Sesungguhnya aku hendak menjadikan seorang khalifah di muka bumi." Mereka berkata. "Mengapa engkau hendak menjadikan (khalifah) di bumi itu orang yang akan membuat kerusakan padanya dan menumpahkan darah, padahal kami senantiasa bertasbih dengan memuji Engkau dan mensucikan Engkau?" Allah berfirman Sesungguhnya aku mengetahui apa yang tidak kamu ketahui"

Berangkat dari hal ayat tersebut, dapat dipahami bahwa kepemimpinan dalam Islam dimaknai sebagai kholifah, di mana dalam proses pelaksanaannya, mereka memiliki karakter yang heterogen dan berbeda antara yang satu dengan yang lainnya. Begitu juga dalam mengelola organisasinya untuk mencapai sebuah tujuan yang telah ditentukan bersama.

Menurut Arifin (2013) dalam kepemimpinan memiliki beberapa fungsi pokok yang harus dijalankan sebagai seorang pemimpin yaitu; pertama, fungsi intruksi yang bersifat komunikasi satu arah agar keputusan dapat dilaksanakan secara efektif. Kedua, fungsi konsultasi yang bersifat komunikasi dua arah, di mana pemimpin dalam membuat keputusan membutuhkan informasi dan bahan pertimbangan. Ketiga, fungsi partisipasi, di mana seorang pemimpin mengaktifkan orang yang dipimpinnya dalam keikutsertaan pada pengambilan keputusan. Keempat, fungsi delegasi, yaitu pelimpahan wewenang dari seorang pemimpin kepada bawahannya untuk menjalankan keputusannya. Kelima, fungsi pengendalian untuk mengatur dan mengendalikan aktivitas anggotanya secara terarah dan dalam koordinasi yang efektif untuk mencapai tujuan.

Stoner (1996) memberikan gambaran tentang dua fungsi utama pemimpin, yaitu fungsi yang berhubungan dengan tugas memecahkan masalah dan fungsi memelihara kelompok atau sosial, artinya bahwa pemimpin dapat menyelesaikan perselisihan diantara mereka dan saling menghargai diantara mereka. Kehadiran pemimpin dengan demikian dapat memberikan makna yang jelas dalam keberadaannya.

Luthans (2011) melakukan observasi tentang peran dan kegiatan terhadap para manajer, dan menemukan bahwa ada tiga jenis peran manajerial pemimpin yaitu; pertama, peran interpersonal yang timbul secara otomatis dari formal otoritas yang merupakan hubungan antara manajer dan bawahannya. Kedua, peran pemimpin adalah menggunakan pengaruhnya untuk memotivasi dan mendorong bawahannya untuk mencapai tujuan organisasi. Ketiga, peran penghubung yaitu pemimpin melakukan komunikasi sebagai bentuk interaksi dengan dunia luar organisasi. 
Al-Tanzim : Jurnal Manajemen Pendidikan Islam E-ISSN: 2549-5720 P-ISSN: 2549-3663

Vol. 03 No. 02 (2019) : 37-48

https:// ejournal.unuja.ac.id/index.php/al-tanzim

Selain dari tiga peran di atas juga tidak kalah pentingnya adalah peran informasi dan peran putusan, di mana kedua peran ini juga mempunyai kedudukan strategis dalam praktek kepemimpinan karena memang peran dan fungsi pemimpin sangat strategis dalam sebuah organisasi (Luthans, 2011). Pandangan ini semakin memperjelas peran pemimpin organisasi dalam interaksi dengan semua orang yang terlibat dalam organisasi, baik masalah tugas dan tanggung jawab, serta motivasi untuk mencapai tujuan bersama.

\section{Partisipasi dalam Kepemimpinan Pesantren}

Dari pandangan di atas, perlu adanya kesepahaman terhadap rumusan pengertian partisipasi yang merupakan keterlibatan seseorang, baik secara langsung maupun tidak langsung, dalam rangka memberikan sumbangsihnya terhadap proses pengambilan keputusan yang dilakukan oleh seorang pemimpin, dalam rangka untuk melakukan perubahan dan rencana strategis pendidikan yang di selenggarakan pada pondok pesantren yang di pimpinnya. Manajemen peran serta (participative management) adalah suatu pendekatan manajemen yang melibatkan manajer bawahan dalam proses pengambilan keputusan (V. R. dan A. Arifin, 2013), kesamaan persepsi ini menjadi penting untuk menghindari salah paham dalam proses perjalanan organisasi yang dapat menimbulkan resistensi terhadap keputusan yang ditetapkan oleh unsur pimpinan yang terlibat.

Partisipasi secara teoritis akademis dalam proses pengambilan keputusan merupakan rancana strategis organisasi sebagai salah satu persoalan utama dalam pengambilan keputusan. Semua warga organisasi dalam perspektif manajemen pengambilan keputusan merupakan strategi untuk meningkatkan keterlibatan ego, motivasi, dan kepuasan mereka (Griffin, 2013). Pondok pesantren sebagai institusi yang secara organisatoris memiliki sistem manajemen yang sama dengan lembaga pendidikan pada umumnya, sehingga dengan demikian sistem organisasi yang digunakan juga menggunakan kaidah-kaidah manajemen yang baku.

Dalam proses pemecahan masalah organisasi, keterlibatan warga organisasi biasanya akan menghasilkan solusi yang lebih banyak dan lebih baik dibanding dengan hanya dilakukan oleh seorang pemimpin atau manajer seorang diri. Proses pengambilan keputusan secara kelompok akan memakan waktu yang lebih lama dalam mengembangkan solusi dan mengambil keputusan.

Keterlibatan kelompok dalam mengambil keputusan ini juga di gambarkan M. Arifin (2015) dalam penelitiannya tentang pengaruh kompetensi, motivasi, dan budaya organisasi menemukan kesimpulan tentang pengaruh budaya, kompetensi, motivasi, dan kompetensi organisasi, sebagai berikut; Pertama. Pengaruh kompetensi untuk kepuasan kerja. Kedua, pengaruh motivasi kepuasan kerja. Ketiga, pengaruh budaya organisasi untuk kepuasan kerja. Keempat, pengaruh kompetensi untuk kinerja. Kelima, pengaruh motivasi 
kinerja terhadap performance dan kreativitas. Keenam, pengaruh budaya organisasi terhadap kinerja. Ketujuh, pengaruh kepuasan kerja terhadap kinerja karyawan.

Oleh karena itu, pelibatan atau pemberdayaan seluruh elemen organisasi dalam proses pendidikan merupakan suatu yang sangat urgen untuk dilakukan oleh para pemangku kepentingan atau pimpinan pondok pesantren, karena keterlibatan semua pihak tentu akan meningkatkan kualitas proses in put menjadi out put yang diharapkan. Proses ini menjadi bagian penting untuk menuju pada kualitas mutu yang menjadi tujuan memiliki relasi yang signifikan. Keterlibatan semua pekerja perlu direncanakan dan dibangun sebuah manajemen sehingga dampak positif yang menjadi harapan dapat menjadi kenyataan.

\section{METODE PENELITIAN}

Penelitian ini menggunakan pendekatan kualitatif deskriptif jenis studi kasus, dengan harapan data yang dihasilkan akan lebih menggambarkan realitas obyetif di lapangan dengan harapan hasil penelitian ini dapat mengungkap fenomena dan gejala serta mendeskripsikan secara menyeluruh dan mendalam tentang proses pengambilan keputusan, partisipasi dalam pengambilan keputusan, dan metode pengambilan keputusan.

Guna mendapatkan data dan informasi yang baik, maka peneliti melakukan kegiatan wawancara secara mendalam terhadap beberapa informan, melakukan observasi dan mendokumentasikan berbagai informasi yang didapat. Sedangkan analisis datanya dilakukan melalui penyajian data, reduksi data dan dilanjutkan dengan penarikan kesimpulan

\section{HASIL PENELITIAN DAN PEMBAHASAN}

\section{Partisipasi dalam Pengambilan Keputusan Strategis di Pondok Pesantren}

Pondok pesantren dengan segala kelebihan dan kekurangannya sebagai institusi pendidikan, memiliki corak dan warna tersendiri yang menjadi keunikan dan ciri khasnya masing-masing. Partisipasi warga pesantren dalam pengambilan keputusan merupakan keterlibatan semua unsur dan orang yang menjadi bagian dalam proses manajemen organisasi dan memberikan sumbangsih untuk kemajuan organisasi, baik itu berupa pikiran/ide, tenaga, dan lain sebagainya. Pikiran para warga organisasi adalah keterlibatan dalam proses pengambilan keputusan, kemudian keterlibatan tenaga untuk implementasi keputusan yang dibuat oleh pimpinan. Keterlibatan warga organsasi dalam pengambilan keputusan dalam bentuk apapun akan dapat memberikan manfaat yang besar untuk meningkatkan kualitas keputusan bagi kemajuan organisasi. 
Al-Tanzim : Jurnal Manajemen Pendidikan Islam E-ISSN: 2549-5720 P-ISSN: 2549-3663

Vol. 03 No. 02 (2019) : 37-48

https:// ejournal.unuja.ac.id/index.php/al-tanzim

Ketelibatan diharapkan bisa meningkatkan hasil keputusan yang berkualitas berdasarkan informasi dari semua pihak, unsur, dan tingkatan struktur yang ada dalam organisasi, baik berupa ide, gagasan, usulan, maupun koreksi terhadap kondisi dan situasi yang sedang terjadi dalam organisasi. Keputusan yang diambil dalam organisasi bisa bersifat individual maupun struktural, sehingga kehidupan demokratis organisasi menjadi kultur yang dipegang teguh dan disosialisasikan kepada semua tingkatan struktur yang bertanggung jawab dalam keputusan yang telah dibuatnya.

Dari studi yang dilakukan oleh peneliti, didapatkan bahwa partisipasi dalam pengambilan keputusan strategis di Pondok pesantren Kyai Syarifuddin, Lumajang dilakukan melalui;

\section{Full Power}

Pengembangan Pondok pesantren Kyai Syarifuddin, Lumajang agar tetap memiliki daya saing tinggi diperlukan terobosan-terobosan dan lompatan cara berpikir yang inovatif. Perkembangan pondok pesantren selalu berbanding lurus dengan perkembangan dunia pendidikan formal yang sedang memiliki nilai tawar positif di kalangan masyarakat, baik masyarakat desa maupun kota. Kondisi ini menuntut para pimpinan pesantren untuk terus mengupdate informasi-informasi seputar perkembangan perubahan dan kebutuhan masyarakat terhadap sumber daya manusia yang dibutuhkan sehingga nilai tawar para lulusan pesantren tetap menjadi perhitungan bagi para pengguna jasa pendidikan.

Pondok pesantren Kyai Syarifuddin, Lumajang telah melakukan berbagai inovasi dan melakukan pengembangan yayasan dalam bentuk pendirian lembaga-lembaga pendidikan formal dan kersajasama dengan berbagai pihak untuk kemajuan pondok pesantren. Pengambilan keputusan strategis pengembangan Pondok pesantren Kyai Syarifuddin, Lumajang menjadi tanggung jawab dan hak penuh Kyai sebagai pemilik dan pengasuh pesantren. Keterlibatan pengurus merupakan masukan ide keputusan teknis untuk implementasi keputusan strategis yang telah ditetapkan oleh Kyai.

Pengambilan keputusan di Pondok pesantren Kyai Syarifuddin, Lumajang sifatnya kelembagaan bukan individual, artinya pengambilan keputusan bersifat struktural organisatoris bukan orang perorang. Jadi semua ide dan orang yang ada dalam struktur bisa terlibat secara aktif dalam proses pengambilan keputusan. Bagaimanapun Kyai tetap menjadi panutan atau penentu terakhir dari semua keputusan, dan semua keputusan berisifat koordinatif. Dalam konteks tertentu, keputusan Kyai tetap tidak bisa ditolak oleh semua tingkatan struktur. Keputusan strategis tetap menjadi hak otoritas Kyai sebagai pemangku pondok pesantren. Kehidupan demokratis organisasi di pondok pesantren menjadi kultur yang dipegang teguh dan disosialisasikan kepada semua tingkatan struktur 
karena keterbukaan semua pimpinan, semua merasa terlibat dan bertanggung jawab dalam keputusan yang telah dibuatnya.

Secara teoritis bahwa keputusan otokratis merupakan keputusan yang dilakukan oleh pemimpin tanpa adanya informasi yang memadai untuk membuat keputusan dan dilakukan sendirian oleh pemimpin. Pondok pesantren Kyai Syarifuddin, Lumajang tidak mengenal istilah otokratis tetapi keputusan yang dilakukan oleh Kyai sebagai pengasuh pesantren yang secara struktural tidak masuk dalam struktur organisasi. Pola komunikasi disusun berdasar pada pola etika pesantren, artinya tingkat ketaatan pengurus terhadap Kyai sebagai pengasuh pesantren sangat tinggi sekali, mayoritas orang yang terlibat dalam tugas struktur organisasi adalah santri atau orang yang pernah hidup di pondok pesantren.

Pola penataan pengambilan keputusan juga berdasar pada budaya pesantren, para pengasuh ini terkadang juga membuat keputusan yang perlu diikuti dan dijalankan, dan semua ini sudah menjadi budaya atau kultur di pondok pesantren. Jadi secara structural, proses pengambilan keputusan di Pondok pesantren Kyai Syarifuddin, Lumajang dilakukan oleh forum pengasuh, kemudian di tetapkan oleh pengasuh. Keputusan ini bukan keputusan otokratis tetapi keputusan pengasuh pesantren berdasarkan kepada kultur yang sudah ada di pesantren sejak lama.

Otoritas yang dimiliki Kyai dalam pengembangan Pondok pesantren Kyai Syarifuddin, Lumajang tidak dipandang sebagai kekuasaan yang bersifat "otoriter" negatif yang sering didengar oleh banyak kalangan, tetapi dengan kharismatik Kyai dan kepribadian luhur yang ditunjukkan dalam pengambilan keputusan, melalui shalat istikharah yang dilakukan, maka Kyai dapat membuat keputusan sendiri berdasarkan hasil dari shalat istikharah itu.

Membuat keputusan berdasarkan shalat istikharah ini tidak dilakukan oleh para pemimpin di luar pondok pesantren. Keputusan yang seperti kita sebut dengan keputusan intuitif religius yaitu keputusan yang dibuat oleh seorang pemimpin dengan intusinya melalui pendekatan religius yaitu shalat istikharah. Keputusan seperti ini bukanlah keputusan otoriter.

Jadi, system pengambilan keputusan di Pondok pesantren Kyai Syarifuddin, Lumajang tidak mengenal istilah "Otoriter" melalui kekuasaan yang dimiliki oleh Kyai. Keputusan Kyai dipandang sebagai suatu kebaikan masa depan pondok pesantren dan dapat memenuhi kebutuhan hidup manusia masa depan. Keputusan yang ditetapkan oleh Kyai adalah keputusan yang bersifat jangka panjang strategis untuk pengembangan dan ketahanan pondok pesantren di masa yang kan datang. 
Al-Tanzim : Jurnal Manajemen Pendidikan Islam E-ISSN: 2549-5720 P-ISSN: 2549-3663

Vol. 03 No. 02 (2019) : 37-48

bttps:/ / ejournal.unija.ac.id/ index.php/al-tanzim

\section{Sharing Power}

Di samping hak penuh keputusan Kyai yang harus diikuti oleh para pelaksana struktur organisasi, tetapi pada konteks dan kondisi tertentu keterlibatan para bawahan dalam menjalan tugas organisasi menjadi bagian yang tidak terpisahkan dalam pengambilan keputusan. Informasi yang disampaikan oleh para bawahan menjadi pertimbangan Kyai dalam membuat keputusan. Kyai selalu bertanya kepada para pembantunya utuk membuat sebuah keputusan organisasi, keputusan yang ditetapkan oleh Kyai berdasarkan kepada usulan yang disampaikan oleh para pengurus di Pondok pesantren Kyai Syarifuddin, Lumajang.

Tipologi kepimimpinan yang ditampilkan oleh Kyai di Pondok pesantren Kyai Syarifuddin, Lumajang memberikan gambaran terhadap proses manajemen dan metode pengambilan keputusan yang digunakan. Partisipasi para bawahan yang secara struktural menjadi bagian dalam proses pengambilan keputusan, realitas kongkrit dalam aktivitas kerja manajemen bahwa keterlibatan mereka secara langsung maupun tidak langsung dapat diidentifikasi, baik dalam keputusan terstruktur maupun keputusan tidak terstruktur, keterlibatan bawahan menjadi bagian integral yang tidak terpisahkan dalam sistem manajemen struktur organisasi.

Dapat diketahui bersama bahwa pimpinan Pondok pesantren Kyai Syarifuddin, Lumajang sangat mengapresiasi terhadap ide, usulan, kritikan dari para bawahannya, beliau sangat terbuka sekali dengan informasi, semua itu selalu dijadikan dasar pertimbangan oleh beliau dalam membuat keputusan, beliau selalu meminta masukan tentang sesuatu yang akan beliau putuskan. Kyai selalu menyampaikan idenya kepada para bawahannnya sebelum beliau memutuskan. Intinya beliau tidak pernah membuat keputusan tanpa pertimbangan para bawahannya. Masukan dari para bawahan itu merupakan bentuk rasa tanggung jawab juga para bawahan terhadap keputusan yang akan ditetapkan, sehingga keputusan itu akan bisa berjalan dengan rencana yang menjadi target kita, namun demikian, para pengurus tetap menghormati keputusan terakhir dari Kyai sebagai pengasuh.

Budaya patron klein yang mungkin ada di pondok pesantren tidak menghambat adanya partisipasi semua elemen struktur dalam organisasi. Patron klein lebih merupakan budaya positif pesantren yang perlu dipertahankan, dan kepemimpinan kharismatik yang menjadi ciri khas kehidupan pesantren masih menjadi budaya yang memberikan pengaruh besar terhadap pengambilan keputusan. Dalam aspek pemecahan masalah, baik internal maupun eksternal yang diterapkan secara konsisten oleh pimpinan pondok pesantren, mereka selalu mengajarkan kepada anggotaanggota baru yang terlibat dalam organisasi yang dipandang sebagai cara yang benar dalam memandang, memikirkan dan merasakan terhadap masalah yang dihadapi. Bahkan, budaya organisasi ini juga mampu 
mengikat dan menyatukan komunitas mereka sebagai lembaga pendidikan yang bercorak islami dalam seluruh praktek manajemen organisasi.

Struktur organisasi di Pondok pesantren Kyai Syarifuddin, Lumajang menggambarkan struktur yang bersifat komprehensif, artinya sistem kepemimpinan menunjukkan adanya keterkaitan terhadap seluruh elemen dalam yayasan pondok pesantren. Pengasuh sebagai pimpinan tertingi memberikan kebebasan kepada semua unsur tingkatan organisasi untuk mengelola dengan baik dan benar, dan mereka tetap bertanggung jawab dan berkoordinasi dengan pengasuh atau yayasan.

Semua level struktur organisasi memiliki kemandirian hak dan tanggung jawab, para pengelola struktur disemua tingkatan. Mereka diberi kebebasan seluas-luasnya oleh pengasuh untuk merecanakan dan melakukan yang terbaik untuk pengembangan organisasinya. Mereka menjadi inspirator, motivator, inovator terhadap semua tingkatan struktur masing-masing. Perencanaan yang dibuat oleh struktur dan lembaga merupakan perencanaan tekhnik pelaksanaan program yang mereka buat berdasarkan keputusan yang buat oleh mereka.

Jadi, keputusan terstruktur merupakan keputusan yang dibuat oleh pihak struktural dan keputusan yang terstruktur juga merupakan keputusan administrasi yang menjadi tanggung jawab lembaga pengelola program. Struktur kerja organisasi dengan demikian dapat memberikan gambaran tegas terhadap pembagian kerja dan wilayah tanggung jawab di semua tingkatan struktur organisasi.

Berangkat dari hal tersebut di atas, dapat dipahami bahwa pengambilan keputusan merupakan tugas yang sangat strategis dalam melaksanakan proses kepemimpinan di Pondok pesantren Kyai Syarifuddin, Lumajang. Pondok pesantren merupakan salah satu organisasi yang bergerak dalam bidang pendidikan, sehingga Kyai sebagai pengasuh pesantren sekaligus sebagai pimpinan di lembaga pendidikan yang dilaksanakan di pondok pesantren.

Pengambilan keputusan yang dilakukan oleh Kyai membutuhkan informasi yang sangat kompleks. Di satu sisi, pengembangan lembaga pendidikan formal menghadapi persaingan yang sangat dinamis, dan pada sisi yang lain, pengembangan pondok pesantren juga harus dilakukan sebagai organisasi institusi penyelenggara pendidikan. Pengambilan keputusan bisa menggunakan metode yang disampaikan oleh Vroom (1973) yaitu metode, otokratis, konsultatif, dan metode keputusan bersama. Ketiga metode pengambilan keputusan tersebut merupakan teori umum yang bayak digunakan oleh para pemimpin. 
Al-Tanzim : Jurnal Manajemen Pendidikan Islam E-ISSN: 2549-5720 P-ISSN: 2549-3663

Vol. 03 No. 02 (2019) : 37-48

Dari data yang dihasilkan di lapangan menunjukkan bahwa; proses kepemimpinan di Pondok pesantren Kyai Syarifuddin, Lumajang telah memiliki sistem organisasi yang sudah modern, artinya bahwa pengorganisasian di pondok pesantren telah memiliki sistem organisasi dengan tugas dan tanggung jawab yang jelas pada semua jenjang stuktur organisasi, sistem kerja telah melalui perencanaan, pengorganisasin, dan evaluasi kerja pada semua jenjang struktur.

Teori-teori kepemimpinan dan pengorganisasian telah menjadi bagian inti dalam sistem kerja mereka, struktur tugas telah terdokumentasi secara baku dalam Standart Operasional Prosedur (SOP) sehingga evaluasi kinerja dapat dilakukan berdasarkan tugas dan tanggung jawab itu. Kondisi ini dapat dilihat di struktur pembagian tugas yang dimiliki oleh pondok pesantren. Mereka telah merancang perencanaan program, baik jangka pendek, menengah, dan program panjang dalam tugas kerja mereka.

Berdasarkan data tersebut, dapat dipahami bahwa pengambilan keputusan yang dilakukan oleh Kyai sebagai pengasuh pondok pesantren maupun pimpinan lembaga pendidikan yang menjadi institusi penyelenggara pendidikan, telah menggunakaan langkah seperti yang dirumuskan oleh Salusu (1996) yaitu; melakukan identifikasi, pengembangan, penyelesaian, dan implementasi/evaluasi terhadap hasil dari pelaksanaan keputusan yang telah ditetapkan dalam rapat keputusan pimpinan.

\section{KESIMPULAN}

Keputusan strategis pengembangan pesantren dalam jangka panjang merupakan otoritas Kyai yang diputuskan bersama-sama dalam forum pengasuh pesantren. Keterlibatan semua elemen, pengurus, para alumni, serta masyarakat pada prinsipnya tetap menjadi pertimbangan Kyai dalam melakukan perencanaan dan pelaksanaan teknik program. Metode pengambilan keputusan yaitu otokratis, konsultatif, dan bersama-sama. Keputusan Kyai dengan metode shalat istikharah sebagai bagian kekhasan pesantren yang berbasis kearifan lokal, tidak ada dalam metode pengambilan keputusan di kalangan para pimpinan organisasi lainnya. 


\section{DAFTAR PUSTAKA}

Arifin, M. (2015). The Influence of Competence, Motivation, and Organisational Culture to High School Teacher Job Satisfaction and Performance. International Education Studies, 8(1), 38-45.

Arifin, V. R. dan A. (2013). Islamic Leadership; Membangun Super Leadership Melalui Kecerdassan Spiritual. Jakarta: Bumi Aksara.

Bashori, B. (2017). Modernisasi Lembaga Pendidikan Pesantren. Jurnal Ilmu Sosial Mamangan, 6(1), 47-60. https:/ / doi.org/10.22202/mamangan.1313

Dlofier, Z. (1982). Tradisi Pesantren; Studi tentang Pandangan Hidup Kyai. Jakarta: LP3ES.

Griffin, M. dan. (2013). Perilaku Organisasi. Jakarta: Salemba Empat.

Gündüz, E. (2014). Participation to Decision Making: Does Manager Choose Opportunity Rather Than Threat. Procedia - Social and Behavioral Sciences 1, 150, 890-898.

Hefniy. (2016). Kyai Leadership in Improving Organizational PErformance in Pesantren. Proceeding, 2nd ICET Theme:"Improving The Quality Of Education And Training Through Strengthening Networking," 324-331.

Luthans, F. (2011). Organizational Behavior An Evidence-Based Approach. Avenue of the Americas, New York: McGraw-Hill/Irwin.

Mager, Ursula; Nowak, P. (2012). Effects of Student Participation in Decision Making at School. A Systematic Review and Synthesis of Empirical Research. Educational Research Review, 7(1), 38-61.

Mulyadi, V. R. \& D. (2010). Kepemimpinan dan Perilaku Organisasi. Jakarta: Rajawali Press.

Northouse, P. G. (2013). Kepemimpinan, Teori dan Praktik. Jakarta: Indeks.

Salusu. (1996). Pengambilan Keputusan Stratejik, Untuk Organisasi Publik dan Organisasi Nonprofit. Jakarta: Grasindo PT. Gramedia.

Stephen P. Robbins, dan T. A. J. (2015). Perilaku Organisasi. Jakarta: Salemba Empat.

Stoner, James A.F. R. Edward Freeman, dan D. R. G. J. (1996). Manajemen. Jakarta: Indeks Gramedia Grup.

Syahrul. (2015). Kepemimpinan dan Inovasi lembaga Pendidikan (Pengalaman Pondok Gontor VII Putera Sulawesi Tenggara). Jurnal Al-Ta'dib, 8(1), 82100.

Vroom, V. H. \& P. W. Y. (1973). Leadership and Decision-Making. University of Pittsburgh Press.

Yukl, G. (2015). Kepemimpinan Dalam Organisasi. Jakarta: Indeks. 